\title{
'Unhappy and Wretched Creatures': Charity, Poor Relief and Pauper Removal in Britain and Ireland during the Great Famine*
}

\begin{abstract}
During the Great Famine (1845-51) hundreds of thousands of Irish refugees fled to Britain, escaping the hunger and disease afflicting their homeland. Many made new lives there, but others were subsequently shipped back to Ireland by poor law authorities under the laws of Settlement and Removal. This article explores the coping strategies of the Famine Irish in Britain, and the responses of poor law authorities to the inflow of refugees with a particular focus on their use of removal. We argue that British poor law unions in areas heavily affected by the refugee crisis adopted rigorous removal policies, and that the non-settled Irish were consequently deeply reluctant to apply for poor relief, doing so only when alternative sources of support were unavailable. Thus, the true scale of Irish hardship was hidden from the official record. The article also explores, for the first time, the experiences of those sent back to Ireland, a country suffering from the devastating effects of Famine. The combination of heavy Irish immigration to Britain and large-scale removals back to Ireland created distrust between the authorities at British and Irish port towns, as both sides felt aggrieved by the inflow of destitute Irish arriving on their shores. At the centre of all this were the Irish poor themselves. Uncertainty, dislocation and hardship were often their experience, and we argue that this endured long after the Famine had ended; that the events of the late 1840s, indeed, created a new reality for the Irish in Britain.
\end{abstract}

During the Great Irish Famine (1845-51) hundreds of thousands of refugees arrived in Britain, fleeing the hunger and disease which afflicted their homeland and, ultimately, caused the deaths of around one million of their compatriots. ${ }^{1}$ Press reports showed how desperate they were: emaciated, starving, and often poorly clothed and shod. ${ }^{2}$ Many managed to make new lives in England, Scotland and Wales, but others were less fortunate. In the weeks, months, even years following their arrival on British shores, tens of thousands would be unceremoniously shipped back to Ireland by poor law authorities under a body of legislation known as the Laws of Settlement and Removal. During the most intense period of Faminerelated immigration (1847-48), close to 50,000 were removed. The mass movement of Irish refugees into Britain, and the subsequent repatriation of many of them, alarmed and angered local officials on both sides of the Irish Sea, particularly at the main ports of disembarkation. In Britain, the authorities claimed that destitute Irish people were being encouraged to emigrate to Britain by landowners and public bodies, who wanted rid of them and paid for

\footnotetext{
* The authors wish to thank the Leverhulme Trust for financial support (grant number RPG-2015-404) which made this research possible.

${ }^{1}$ C. Ó Gráda, Black ' 47 and Beyond: The Great Irish Famine in History, Economy and Memory (Princeton, NJ, 1999); C. Kinealy, This Great Calamity: The Great Irish Famine, 1845-52 (Dublin, 1994).

${ }^{2}$ F. Neal, Black'47: Britain and the Famine Irish (London, 1997), pp. 123-76.
} 
their passage over. In Ireland, there were frequent complaints about unjust and illegal removals from Britain, and about paupers being left penniless at Irish ports located considerable distances from their home parishes. In the middle of all this were the non-settled Irish themselves, who faced the very real prospect of being sent back to a country in the grip of famine and pestilence if they applied for poor relief.

For all the attention directed in recent decades towards the Irish in Britain, the issue of enforced repatriation under the auspices of British poor law authorities has been conspicuously neglected. Even studies focusing on the Famine period, when some authorities zealously exercised their powers to remove Irish paupers, have often neglected the subject. ${ }^{3}$ The exception is the work of Christine Kinealy, who considers removal as a function of the national government's refusal to amend the law of settlement. ${ }^{4}$ But before, during and after the Famine, removal hung over the non-settled Irish in Britain as a perpetual threat which could quickly become a reality. Often lacking the kinship support networks of the nativeborn, and facing ethnic and religious prejudice, the Irish were grossly over-represented in British removal statistics during the 1840s and 1850s.

Removal, in a very real sense, separated members of Britain's Irish-born population from their English and Scottish counterparts, who rarely faced being returned to their home parishes. Much of this is apparent from the work of Frank Neal, whose Black '47, which brought together a number of his earlier studies, marks the most important contribution to our understanding of Irish removals in a British context. ${ }^{5}$ Neal argued that the application of strict removal policies in Britain in the wake of the Irish influx had the effect of deterring many non-settled Irish from applying for relief — a significant point with which we concur. Yet his conclusion that removing the Irish simply represented a 'harsh ... penny pinching' move by poor law authorities determined to protect the rates is open to contention. ${ }^{6} \mathrm{We}$ argue that, while this was certainly one aspect, British removal policy during the Famine also formed part of a set of wider public health strategies at the local level to deal with problems of severe overcrowding and epidemic disease, with which the Irish refugees were associated. A weakness of Neal's work, and indeed a lacuna in the historiography of Irish removals from Britain more generally, is the absence of any detailed research into what happened to these

\footnotetext{
${ }^{3}$ See, for example, T.M. Devine, 'The Great Irish Famine and Scottish History', in M. Mitchell, ed., New Perspectives on the Irish in Scotland (Edinburgh, 2008), pp. 20-30.

${ }^{4}$ Kinealy, This Great Calamity, pp. 335-41.

${ }^{5}$ Neal, Black '47; F. Neal, 'The English Poor Law, the Irish Migrant and the Laws of Settlement and Removal, 1819-1879', in D.G. Boyce and R. Swift, eds., Problems and Perspectives in Irish History since 1800 (Dublin, 2004), pp. 95-116.

${ }^{6}$ Neal, Black' 47 , p. 280.
} 
Irish paupers, tens of thousands of them during the Famine, once they left British shores and landed in Ireland. As will become clear, during the late 1840s the arrival of masses of destitute deportees at Irish ports became a subject of enduring controversy between poor law authorities on either side of the Irish Sea.

The harsh regulatory reaction to Irish immigration during the Famine is a central theme in Hidetaka Hirota's important study of the development of immigration policy in North America. This work reminds us that the systematic removal of Irish paupers was not restricted to the British side of the Atlantic. Our research thus helps to create a rounded picture of the process of removal in the context of an Irish diaspora that was hugely expanded by the Famine. Hirota finds that the influx of refugees to New York and Massachusetts during the Famine, many of whom arrived in terrible ill health following long journeys on crowded, insanitary 'coffin ships', was the catalyst for stricter immigration controls and deportation policies along the Atlantic seaboard. Policies were shaped by 'economic concerns about Irish immigrants' poverty, inflated by cultural prejudice against them'. ${ }^{7}$ In the state of Massachusetts, with its strong anti-Irish, anti-Catholic traditions, tough deportation policies were introduced which led to the removal of thousands of Irish during the second half of the nineteenth century. ${ }^{8}$ Some were disembarked penniless at the wharves of Liverpool, much to the chagrin of the authorities there.

This article seeks to illuminate the much larger British dimension of the story of Famine removals in the Atlantic world, building on, and considerably extending the scope of, previous studies of Irish immigration to Britain during the Famine. We achieve this in two main ways. First, we examine the use (and misuse) of removal in Britain within the wider welfare framework in which the poor law operated. Not all Famine refugees were removed. Indeed, the vast majority were not. The article therefore not only asks why some were removed and examines the conditions under which such removals took place, but also investigates how others were able to avoid removal. This means looking at the range of statutory (i.e. poor law) and non-statutory (i.e. charitable) resources available to the nonsettled Irish at a local level within what has been termed the 'mixed economy of welfare'; that is, the various kinds of assistance the poor could draw upon in times of need. ${ }^{9}$ Secondly,

\footnotetext{
${ }^{7}$ H. Hirota, Expelling the Poor: Atlantic Seaboard States and the Nineteenth-Century Origins of American Immigration Policy (New York, 2017), p. 71.

${ }^{8}$ Ibid., esp. ch. 5.

${ }^{9}$ For detailed discussions of the mixed economy of welfare as a concept, see J. Innes, "“The Mixed Economy of Welfare" in Early Modern England: Assessments of the Options from Hale to Malthus (c.1683-1803)', in M. Daunton, ed., Charity, Self-Interest, and Welfare in the English Past (London, 1996), pp. 139-80; S. King and A. Tomkins, eds., The Poor in England, 1700-1850: An Economy of Makeshifts (London, 2003).
} 
we offer the first in-depth consideration of the responses of the Irish authorities to repatriation; the experiences of those removed to Ireland; and the controversy that emerged from the combination of heavy Irish immigration into Britain and large-scale removals back to Ireland. In exploring these issues, we focus on the main areas of Irish immigration in Britain during the Great Famine, and the destinations to which migrants were chiefly repatriated in Ireland. In Britain, these were the urban industrial districts of north-west England and the central lowlands of Scotland, where the major ports of Liverpool and Glasgow received more Irish Famine refugees than anywhere else in the country. In Ireland, we focus on the east-coast port cities of Belfast and Dublin, where the overwhelming majority of Irish removed from Britain during the Famine were banished.

During the years of 1847 and 1848 [there were] frequently 600-800 [Irish] deck passengers on board one of those steam packets, crowded together on deck, mixed among the cattle and besmeared by their dung, clothed with rags and saturated with wet ... so that on their arrival, fatigued by the passage, and the want of proper food and clothing, many of them have been unable to go ashore without assistance, and by all appearances were not likely to survive many days. ${ }^{10}$

Testimony of Inspector Johnson, an officer stationed at the docks in Liverpool, 1849

During 'Black '47', the worst year of the Great Famine in Ireland, some 116,000 Irish refugees arrived in Liverpool by steamer. ${ }^{11}$ A further 50,000 went to Glasgow. ${ }^{12}$ The influx tapered off gradually thereafter, but numbers remained high into the 1850s. In Liverpool, officers at the docks, who counted and assessed the means of every Irish man, woman and child disembarking, estimated that some 94,000 'paupers' (destitute people with little or no means of supporting themselves) arrived in $1848,80,000$ in $1849,78,000$ in $1850,68,000$ in $1851,78,000$ in 1852 and 71,000 in $1853 .{ }^{13}$ This was the number which, the officers suspected, came over with the intention of remaining in the country. They were distinguished from the generally more affluent Irish who arrived on business, or with the intention of

\footnotetext{
${ }^{10}$ Irish Steamers: Captain Denham's Report on Passenger Accommodation in Steamers between Ireland and Liverpool, British Parliamentary Papers [hereafter BPP], House of Commons Papers, 1849, vol. li, no. 339, p. 19.

${ }^{11}$ Report from the Select Committee on Poor Removal; Together with the Proceedings of the Committee, Minutes of Evidence, Appendix, and Index, BPP, House of Commons Papers, 1854, vol. xvii, no. 396, p. 358.

${ }^{12}$ Glasgow City Archives [hereafter GCA], D-HEW 1/1/1, Glasgow Parochial Board minute books, 30 Nov. 1847.

${ }^{13}$ Report from the Select Committee on Poor Removal, 1854, pp. 359, 593.
} 
emigrating to North America. ${ }^{14}$ In total, 33 per cent of immigrants arriving in Liverpool between 1847 and 1853 were thought to be 'paupers', with annual proportions ranging from 39 per cent in 1847 to 24 per cent in 1851 . The arrival of this conspicuous mass of destitution immediately alarmed local authorities in Liverpool and Glasgow, not least because of the pecuniary burden they threatened to place on ratepayer-funded institutions such as the poor law. The Famine Irish were also associated with severe outbreaks of epidemic typhus_-'Irish fever', as it was labelled — which began in Britain at the beginning of 1847 and endured well into the first half of 1848. In England, the north-west was affected particularly badly by the epidemic, and the Registrar General report looked no further than mass Irish immigration into the region as the chief cause. ${ }^{15}$ This, then, was not only a refugee but also a public health crisis.

After arriving in Liverpool or Glasgow, many Irish refugees required assistance in some form or other from the various welfare institutions operating in those places and further afield. The statement by Inspector Johnson which opened this section shows how desperate the immigrants were, and Neal has described the difficulties they faced as they sought accommodation and employment, both of which were hard to come by in the late 1840s. The influx of Famine refugees, which began around November 1846, placed considerable strain on housing stock, leaving many with little choice but to reside in miserably overcrowded cellars and lodging houses. ${ }^{16}$ Work was also scarce, particularly in the northern counties, as the manufacturing districts in 1847 and 1848 were badly affected by economic depression which caused widespread unemployment. Welfare in Britain was principally governed by the provisions of the 1834 Poor Law Amendment Act, a system operated at the local level by boards of guardians who oversaw hundreds of semi-autonomous units of administration. The English and Scottish poor laws varied slightly on certain legislative points, but their fundamental principles were largely the same, particularly where non-settled paupers were concerned. In short, such people, including the Famine Irish, had no legal right to long-term relief. While poor law authorities had an obligation to provide relief to all people in desperate need, applicants without a settlement could be removed by warrant. ${ }^{17}$ For the non-settled Irish, this meant being shipped back home. A significant amendment to the settlement laws in

\footnotetext{
${ }^{14}$ Ibid., p. 358. See also Kinealy, This Great Calamity, pp. 297-341.

${ }^{15}$ Ninth Annual Report of the Registrar General of Births, Deaths, and Marriages, in England, BPP, 1847-48, vol. xxv, Command Paper 996, pp. xxviii-xxxii; Tenth Annual Report of the Registrar General (London, 1852), p. Xviii.

${ }^{16}$ Neal, Black'47, p. 108 and pp. 177-216.

${ }^{17}$ See Neal, 'English Poor Law', pp. 95-116.
} 
1846 granted 'irremovable' status to all people who resided in the same parish for five years or more, but this was of no immediate benefit to the mass of Irish refugees arriving during the Famine. ${ }^{18}$ There was, however, a further important regulation which was of some benefit. Paupers could not be removed when they were sick. Illness therefore granted de facto temporary irremovable status to the Famine Irish. As the typhus epidemic advanced in 1847 , this placed a tremendous burden on the poor law system in British towns and cities as thousands of Irish refugees sought medical care.

Non-settled Irish paupers were by no means all removed from Britain, even they were healthy. It was frequently much cheaper and more convenient to provide a non-settled applicant with a small sum of outdoor relief than to initiate removal proceedings. Often, removal took place only if the applicant looked likely to be a long-term burden on the rates. There was little reason, for example, to remove an itinerant Irish applicant, and many such people spent nights in workhouses and vagrant wards without facing removal. The Irish were, however, disproportionately likely to be removed-before, during and after the Great Famine. In Scotland, of 50,658 paupers-men, women and children — removed between 1846 and 1853, no less than 92 per cent were Irish. Some of these removals, we should note, were made under a 'voluntary' arrangement meaning the pauper ostensibly agreed to be sent home; more on which later. ${ }^{19}$ In England and Wales, we only have figures for the number of removal warrants issued, rather than the number of individuals removed, and thus, regrettably, there is no comparable data for the late $1840 \mathrm{~s} .{ }^{20}$ Nor do we know how many paupers removed themselves voluntarily. Still, during the year ending 25 March 1853, a total of 9,072 removal orders were signed by English justices, 53 per cent of which applied to Irish paupers. Moreover, if we isolate the county of Lancashire in north-west England, which by 1851 had the largest Irish-born population in England, 91 per cent of 4,187 removals applied to the Irish. ${ }^{21}$

There are a number of reasons why the Irish featured so prominently in English and Scottish removal statistics. In part, it was a result of Irish labourers taking advantage of the system. David Fitzpatrick has pointed to the many Irish seasonal workers who came to Britain during the harvest and used the removal system for a free passage home, much to the

\footnotetext{
${ }^{18}$ L. Darwen, 'Implementing and Administering the New Poor Law in the Industrial North: A Case Study of Preston Union in Regional Context, 1837-61' (Nottingham Trent Univ. Ph.D. thesis, 2016), pp. 194-216.

${ }^{19}$ Report from the Select Committee on Poor Removal, 1854, pp. 570-71.

${ }^{20}$ A single removal warrant might include several people, as in the case of a family.

${ }^{21}$ Poor Law (Orders of Removal). Returns Showing the Number of Orders of Removal from Parishes, Signed by Justices, and Executed in England and Wales, During the Year Ending 25 March 1853, BPP, House of Commons Papers, 1854, vol. lv, no. 87, p. 7.
} 
annoyance of the authorities at the main exit ports of Liverpool and Glasgow, who had to pay for the crossing. ${ }^{22}$ Such strategic use, however, probably accounted for no more than a small minority of removals, and in any case, as we have seen, the Irish were also predominant among those removed forcibly by warrant.

In fact, the wider context for removal, as Hirota also found for the US, was an ingrained and increasingly intense hostility towards Irish Catholics. During the 'Hungry Forties', Irish workers were not alone in struggling to find stable employment, and their enlarged numbers exacerbated nativist hostility among British workers. Anti-Catholic prejudice surfaced spectacularly in 1850 in the wake of the so-called 'Papal Aggression', when the Catholic Church re-established its hierarchy in Britain for the first time since the Reformation) ${ }^{23}$ Since the Famine influxes had barely subsided by the time the 'Aggression' controversy erupted, it had a notably adverse effect on the already unhappy experiences of the Irish in Britain. Working-class anti-Catholicism took many forms, including a resurgence of the Orange Order in Lancashire and Scotland, while regular street rioting and ritualised drink-related brawling became much more noticeable features of relations between the increasingly beleaguered Irish communities and their hosts. ${ }^{24}$ Allied to this were negative perceptions of the Irish character, which hardened in Britain during the Famine. Descriptions of the Irish as disease-carrying mendicants, profligate and feckless, were rife in the late 1840s and endured for many years. As McCaffrey writes of Scotland, '[s]tereotypes of the Irish were formed from the experiences ... of the dark days of the late 1840s and early 1850 s which proved particularly long lasting' ${ }^{25}$ One manifestation of this was a pervasive fear that large numbers of non-settled Irish would, given half a chance, throw themselves on the mercy of the poor law authorities. As a relieving officer in the industrial town of Ashton-under-Lyne, northwest England, stated in 1847, '[t]o administer outdoor relief to the Irish is except in very extreme circumstances almost sure to result in gross imposition' ${ }^{26}$ Only with the threat of

\footnotetext{
${ }^{22}$ D. Fitzpatrick, 'A Peculiar Tramping People: The Irish in Britain, 1801-70', in W.E. Vaughan, ed., A New History of Ireland: Ireland under the Union, 1801-70 (Oxford, 1989), pp. 263-59.

${ }^{23}$ W. Ralls, 'The Papal Aggression of 1850: A Study in Victorian Anti-Catholicism', in G. Parsons, ed., Religion in Victorian Britain, IV: Interpretations (Manchester, 1988), pp. 115-34.

${ }^{24}$ On the Orange dimension of communal anti-Catholicism, see D.M. MacRaild, Faith, Fraternity and Fighting: The Orange Order and Irish Migrants in Northern England, c.1850-1920 (Liverpool, 2005), ch. 5; on crime and violence, see R. Swift, 'Crime and the Irish in Nineteenth-Century Britain', in id. and S. Gilley, eds., The Irish in Britain, 1815-1939 (London, 1989), pp. 163-82.

25 J.F. McCaffrey, 'Reactions in Scotland to the Irish Famine', in S. Brown and G. Newlands, eds., Scottish Christianity in the Modern World (Edinburgh, 2000), p. 158.

${ }^{26}$ The National Archives [hereafter TNA], MH 12/5415, Ashton-under-Lyne Poor Law Union correspondence, 15 Dec. 1847.
} 
removal, he argued, were the Irish kept at bay. The strong associations between Irish immigrants and disease, particularly during the outbreaks of epidemic typhus in 1847-48, further ensured that the Irish were prime targets for removal. They were concentrated in the worst slum areas in British towns, which became grossly overpopulated during the Famine and were breeding grounds for epidemic disease. Temporary fever hospitals were hastily opened in many urban centres in north-west England and central Scotland during the first half of 1847, and their patients were overwhelmingly Irish. ${ }^{27}$ Removing the non-settled Irish was, in part, a way of dealing with this public health problem, as it mitigated the worst of the overcrowding in slum areas and so reduced the size of the community that might later contract and spread disease.

Nativist and cultural prejudices aside, it was true that the Irish in Britain were more likely to require and apply for relief than the population in general, and this is borne out in the ethnic composition of removal. The Famine influx placed considerable pressure on wellestablished Irish settlements, which simply could not cope with the numbers arriving in the later 1840s. ${ }^{28}$ Large-scale migration generally weakened kinship networks and lessened the chances of families already established in Britain being able to help newly arrived kin. This was particularly the case in the late 1840 s because, as we have noted, employment in industrial regions was scarce. Familial connections were always more easily maintained by natives, even those who moved away from home for work, since such migrations tended to be over relatively short distances. In the north-west of England, many young men and women moved from villages to industrial towns for work, but rarely did they travel further than twenty miles; often they ventured much less far. ${ }^{29}$

English and Scottish parishes were also keen to avoid expensive removal proceedings within Britain for paupers for whom they were responsible, often making arrangements to reimburse relief paid to their paupers living elsewhere. ${ }^{30}$ This system was known as 'nonresident relief', whereby a non-settled pauper would be granted relief in the parish where they were living, under the assumption that the parish of their legal settlement would refund the

\footnotetext{
27 Gore's Liverpool General Advertiser, 11 Mar. 1847; Manchester Times, 2 July 1847; TNA, MH 12/6176, Rochdale Poor Law Union correspondence, Ashton-under-Lyne correspondence, 26 Sept. 1847; Bolton Archives, GBO/5/4, Bolton fever hospital register of deaths, 1847; TNA, MH 12/6221, Salford Poor Law Union, analysis of expenditure, 1848; GCA, D-HEW 1/1/1, Glasgow Parochial Board minute books, 30 Nov. 1847; Edinburgh City Archives [hereafter ECA], SL8/2, Parochial Board minute books, 30 Dec. 1847.

${ }^{28}$ D.M. MacRaild, The Irish Diaspora in Britain, 1750-1939 (Basingstoke, 2010), pp. 22-30.

${ }^{29}$ M. Anderson, Family Structure in Nineteenth-Century Lancashire (Cambridge, 1971), pp. 34-6.

${ }^{30}$ See K.D.M. Snell, Parish and Belonging: Community, Identity and Welfare in England and Wales, 17001950 (Cambridge, 2006), p. 137 and Darwen, 'Implementing and Administering the New Poor Law', pp. 199200.
} 
payment. This obviated the need for removals, which could be costly, and was widely used until the 1850s. No such option was available to the Irish, as there was no parish-based settlement system in Ireland, and such arrangements would, in any case, have been logistically difficult. Evidence from Liverpool shows that in 1849-50 over 90 per cent of paupers removed to Ireland had been in England for less than one year, many no doubt having failed to obtain the means of supporting themselves. ${ }^{31}$ Later, in the mid-1850s, the Irish still accounted for the highest proportion of paupers and vagrants in Liverpool. ${ }^{32}$ When the Famine Irish first began coming to Britain in large numbers, from around November 1846, many immediately applied for poor relief but did not face removal. Their number was too large, and their arrival so sudden that they overwhelmed the unprepared authorities at Liverpool and Glasgow. In the City Parish of Glasgow, over 4,500 Irish people received relief in January 1847 alone, compared to 750 during the same month in 1846. While not all these were Famine Irish, observers noted the 'enormous number of Irish vagrants poured upon us by every steamer that arrived in the Clyde'. ${ }^{33}$ Compared to Liverpool, however, the situation in Glasgow was relatively mild. In response to huge numbers of 'half naked and starving' Irish refugees arriving in Liverpool each day, the poor law authorities began providing soup and bread almost indiscriminately. By the end of January 1847 , more than 25,000 Irish paupers were receiving this provision every day. Faced with such numbers, and suspecting that they were being imposed upon, the guardians immediately took steps to tighten the system. ${ }^{34}$ In February, relief divisions were formed in the town, each with its own committee and inspectors, and the circumstances of every applicant were assessed before relief was approved. The result was an immediate and substantial drop in the numbers relieved (fig. 1). Still, plateauing at around 9-10,000 relieved each day between February and April 1847, the Famine Irish remained a considerable andas more and more poured in each week-seemingly never-ending economic burden on the town.

In both Liverpool and Glasgow, the parochial authorities petitioned the government for assistance on several occasions during the first half of 1847. Arguing that the responsibility of supporting the paupers arriving daily from Ireland should not fall entirely upon the

\footnotetext{
${ }^{31}$ Report from the Select Committee on Poor Removal, 1854, p. 408.

${ }^{32}$ Report from the Select Committee on Poor Removal; Together with the Proceedings of the Committee, Minutes of Evidence, Appendix and Index, BPP, House of Commons Papers, 1854-55, vol. xiii, no. 308, pp. $329-32$.

${ }^{33}$ Glasgow Herald, 5 Mar. 1847.

34 Poor Law Commissioners: Appendices to the Thirteenth Annual Report. Plans, BPP, 1847, vol. xxviii, Command Paper 873, pp. 111-15.
} 
shoulders of local ratepayers, they asked for restrictions to be placed on the number of destitute Irish coming over; for financial assistance with their relief efforts; and for the Irish poor law to grant outdoor relief as a right. ${ }^{35}$ On this last point, it was thought that the Irish were encouraged to come to Britain because outdoor relief was granted more liberally there than in Ireland itself. None of these claims were, however, conceded; on the main problem of immigration there was little the government could do, short of restricting movement between Britain and Ireland, something which was never a serious option. While the Irish poor law was reformed midway through 1847 to allow for the greater provision of outdoor relief, the Liverpool authorities felt the change was insufficient, as 'the facilities for gaining relief in England [still] so greatly exceed that of Ireland'. ${ }^{36}$ Increasingly, removal became the main way of dealing with the non-settled Irish. This was particularly the case after the success, in June 1847, of a campaign by the Liverpool authorities for the process of removal to be simplified. From this point, poor law authorities could remove Irish paupers on the same day as their application, rather than having to wait to bring them before two magistrates to be served a warrant. ${ }^{37}$

The implications of all this for the number of Irish removed from Britain during the Famine can be observed in Tables 1 and 2. Table 1 contains detailed county-level data for Scotland during the period 1846-53, taken from a statistical report presented to a Select Committee inquiring into removal practices in $1854 .{ }^{38}$ The evidence is unique, as it reveals not only the number of non-settled Irish paupers removed from Scotland each year, but also the proportion. The five counties featured in the table-Ayrshire, Edinburgh, Forfar, Lanarkshire and Renfrewshire-were collectively responsible for the overwhelming majority (96 per cent) of Irish removals from Scotland during these years. It is immediately apparent that all these counties, to varying degrees, felt the effects of the crisis years of 1847-48, when large-scale Irish immigration coincided with economic depression and outbreaks of epidemic disease. The number of non-settled Irish paupers, and the number who were subsequently removed, rose considerably at this time. The proportion removed was also generally higher, pointing to the application of more stringent removal policies at local level. This is particularly apparent in Ayrshire in 1847 and Forfar in 1848, but even in Lanarkshire the fact that almost one in every two non-settled Irish paupers was removed in 1847-48, when a great

\footnotetext{
${ }^{35}$ Gore's Liverpool General Advertiser, 28 Jan. 1847; Liverpool Mercury, 30 Apr. 1847; GCA, D-HEW 1/1/1, Glasgow Parochial Board minute books, 6 Mar. 1847 and 4 June 1847.

${ }^{36}$ Liverpool Mercury, 30 Apr. 1847.

${ }^{37}$ See Neal, Black'47, pp. 220-22.

${ }^{38}$ Report from the Select Committee on Poor Removal, 1854, pp. 570-81.
} 
many must have been the sick and malnourished refugees arriving daily in Glasgow, is significant. Clearly, the threat of removal was no idle one, and some Scottish poor law unions were returning very substantial numbers of Irish back home during the Great Famine.

This general pattern aside, the variation between Scottish counties is striking. The vast majority of Scotland's Irish-born population, some 81 per cent, resided in these five counties, but there were of course considerable differences between them, and factors such as distance from the main ports along the Clyde, the scale of Famine Irish immigration into each county, and the density of Irish settlements, were all significant determinants of removal practices. In Forfar, for example, the principal town, Dundee, had a considerable Irish-born population before the Famine, most of whom were Catholic, and huge numbers of Famine Irish arrived from late 1846 in search of kin, friends and employment. ${ }^{39}$ Between 1841 and 1851, the number of Irish-born in Dundee increased almost threefold, representing 19 per cent of the population by the latter year. Yet after 1848 relatively few non-settled Irish were removed. It is likely that, being situated on the east coast some 75 miles from Clydeside, the logistical difficulties and high costs of removing the Irish meant it was generally avoided in normal times. The county of Ayrshire, on the other hand, also removed the Irish infrequently despite lying on the west coast. The low incidence of Irish removals here is probably explained by the fact that the county's Irish-born population, despite numbering nearly 20,000 by 1851 , was widely scattered, with the result that Irish pauperism did not become a major problem requiring strict remedy in any single locality; the exception was the year of $1847 .{ }^{40}$ Indeed, it was in those counties situated a convenient distance from western seaboard ports, and where the inflow of Irish refugees was both pronounced and highly concentrated, that removals were most prominent during the Famine. The Lanarkshire city of Glasgow is the most notable example, but Greenock and Paisley in neighbouring Renfrewshire also attracted and removed huge numbers of Irish during 1847-48. ${ }^{41}$ The county of Edinburgh falls into the same category. Here, good transport links to the Clyde by rail meant that the non-settled Irish, large numbers of whom were drawn to the capital during the Famine, could be easily and cheaply removed.

\footnotetext{
${ }^{39}$ R. McReady, 'The Social and Political Impact of the Irish in Dundee, c.1845-1922' (Univ. of Dundee Ph.D. thesis, 2002), pp. 16-18.

${ }^{40}$ MacRaild, Irish Diaspora in Britain, pp. 49-51. It is likely that the lower number of Irish paupers in Ayrshire in 1847 compared to the years that followed was the result of strict removal policies (in 1847, 300 were removed) deterring them from applying for relief.

${ }^{41}$ R.D. Lobban, 'The Irish Community in Greenock in the Nineteenth Century', Irish Geography, vi (1971), pp. $270-81$.
} 
Table 1. Irish pauperism and removals (adults and children), Scotland, 1846-53

\begin{tabular}{|c|c|c|c|c|c|c|c|c|c|}
\hline \multirow{2}{*}{ Year } & \multicolumn{3}{|c|}{ Ayrshire } & \multicolumn{3}{|c|}{ Edinburgh } & \multicolumn{3}{|c|}{ Forfar } \\
\hline & 1 & 2 & 3 & 1 & 2 & 3 & 1 & 2 & 3 \\
\hline 1846 & 286 & 26 & 9 & 950 & 205 & 22 & 385 & 221 & 57 \\
\hline 1847 & 681 & 300 & 44 & 2,302 & 497 & 22 & 631 & 264 & 42 \\
\hline 1848 & 809 & 94 & 12 & 1,905 & 820 & 43 & 775 & 543 & 70 \\
\hline 1849 & 922 & 93 & 10 & 1,046 & 581 & 56 & 292 & 65 & 22 \\
\hline 1850 & 748 & 56 & 7 & 1,180 & 453 & 38 & 355 & 66 & 19 \\
\hline 1851 & 678 & 82 & 12 & 854 & 361 & 42 & 301 & 58 & 19 \\
\hline 1852 & 908 & 58 & 6 & 666 & 460 & 69 & 272 & 58 & 21 \\
\hline 1853 & 953 & 64 & 7 & 666 & 257 & 39 & 409 & 84 & 21 \\
\hline \multirow[t]{3}{*}{ Total } & 5,985 & 773 & $12(A v)$. & 9,569 & 3,634 & 38 (Av.) & 3,420 & 1,359 & 40 (Av.) \\
\hline & \multicolumn{3}{|c|}{ Lanarkshire } & \multicolumn{3}{|c|}{ Renfrewshire } & \multicolumn{3}{|c|}{ Rest of Scotland } \\
\hline & 1 & 2 & 3 & 1 & 2 & 3 & 1 & 2 & 3 \\
\hline 1846 & 6,916 & 3,095 & 45 & 662 & 272 & 41 & 770 & 89 & 12 \\
\hline 1847 & 16,808 & 8,147 & 48 & 2,352 & 1,140 & 48 & 2,461 & 370 & 15 \\
\hline 1848 & 19,035 & 8,093 & 43 & 1,813 & 766 & 42 & 2,808 & 381 & 14 \\
\hline 1849 & 15,468 & 6,059 & 39 & 1,071 & 405 & 38 & 2,662 & 265 & 10 \\
\hline 1850 & 9,774 & 4,002 & 41 & 725 & 158 & 22 & 2,051 & 224 & 11 \\
\hline 1851 & 8,037 & 3,807 & 47 & 823 & 157 & 19 & 1,539 & 230 & 15 \\
\hline 1852 & 5,350 & 1,694 & 32 & 738 & 220 & 30 & 1,743 & 185 & 11 \\
\hline 1853 & 4,152 & 837 & 20 & 608 & 159 & 26 & 1,664 & 159 & 10 \\
\hline Total & 85,750 & 36,544 & $43(A v)$. & 8,792 & 3,277 & 37 (Av.) & 15,698 & 1,903 & $12(A v)$. \\
\hline
\end{tabular}

Source: Report from the Select Committee on Poor Removal; Together with the

Proceedings of the Committee, Minutes of Evidence, Appendix, and Index, BPP, House of

Commons Papers, 1854, vol. xvii, no. 396, pp. 570-77.

KEY:

1: The total number of removable Irish paupers.

2: The number of removable Irish paupers actually removed.

3: Per cent of Irish paupers removed.

Note: The data in all tables includes adults and children since no distinction was made by age.

595.

Table 2. Irish removals from Liverpool and Manchester (adults and children), 1846-53

\begin{tabular}{cccc}
\hline Year & Liverpool & Manchester & Total \\
\hline 1846 & 5,313 & 553 & 5,866 \\
1847 & 15,008 & 1,902 & 16,910 \\
1848 & 7,606 & 617 & 8,223 \\
1849 & 9,409 & 275 & 9,684 \\
1850 & 7,627 & 400 & 8,027 \\
1851 & 7,808 & 337 & 8,145 \\
1852 & 5,506 & 362 & 5,868 \\
1853 & 4,503 & 553 & 5,056 \\
Total & 62,780 & 4,999 & 67,779 \\
\hline
\end{tabular}

Source: Report from the Select Committee on Poor Removal, 1854, pp. 445, 
The situation in England was largely the same as in Scotland, although the evidence base is less revealing. Removal figures for individual poor law unions were not published until the early 1850s, which means that evidence from the Famine years must be gleaned from ad hoc sources. Fortunately, such information does exist for the two major urban centres of north-west England-Liverpool and Manchester-for the same period as the Scottish data (Table 2). These two towns were responsible for the vast majority of Irish sent home from England at the mid-century. In 1852-53, for example, Liverpool alone accounted for 74 per cent of Irish removals, and it is likely that the proportion would have been much higher during the Famine. ${ }^{42}$ As with the industrial districts of Lanarkshire and Renfrewshire, the effects of the Irish refugee crisis in Liverpool and Manchester in 1847 are strikingly apparent. The number of Irish removed increased almost threefold in the former and fourfold in the latter. As in Edinburgh, good transport networks allowed the Manchester poor law authorities to send large numbers of Irish to the west coast (in this case to Liverpool, some 35 miles away). Removal was thus relatively easy and low-cost. In that other major centre of Irish immigration, London, geography precluded large-scale removals for reasons of expense. This was outlined by a London relieving officer in the early 1850s:

We try to get rid of them [the Irish poor] as much as we can, without taking out orders of removal. The removals are always attended with great expense. They cost us from $2 l$. to $3 l$. each. We avoid that. Sometimes, by making them work in the stoneyard, we get rid of them ... A threat of taking them into the house, and removing them to Ireland, will make them leave us. They have universally a great dread of being sent back to Ireland. ${ }^{43}$

Robert Pashley, a member of Her Majesty's Council, elaborated on this point in evidence to the 1854 Select Committee on poor removal, distinguishing between London and the northwest:

At Liverpool ... the parish officer saves the money of ratepayers by removing a family to Ireland, at an expense of $10 \mathrm{~s} . .$. whereas the same family, if chargeable in St. Mary-le-bone, could not be removed to Ireland for less than $6 l$. or $7 l{ }^{44}$

\footnotetext{
${ }^{42}$ Poor Law (Orders of Removal), pp. 1, 7.

${ }^{43}$ Report from the Select Committee on Poor Removal, 1854, p. 665.

${ }^{44}$ Ibid.
} 
Distance from Ireland meant that Irish paupers in London, like those in Forfar, were unlikely to face removal proceedings. The lower incidence of removal, however, does not necessarily indicate better treatment. The authorities just tried other ways of getting rid of the non-settled Irish.

The consequences of tough removal policies for the gender composition of Irish paupers removed during the Famine is indicated in Table 3. It provides data for Scotland, comparing removals in 1847-48, at the height of the Famine, with 1853-54, when the Famine had abated. The results are interesting. During the Famine period, males made up a narrow majority of removals. ${ }^{45}$ In $1853-54$, on the other hand, the overwhelming majority were females. Most refugees during the Famine were adult males, so we should perhaps expect males to be predominant in $1847-48 .^{46}$ It is also likely that, for a number of reasons, proportionately more adult males applied for relief during the Famine years than did so in 1853-54 when conditions in Ireland had improved. As several officials interviewed by the Select Committee in 1854 stated, removals at that time consisted almost entirely of women with children (whose husbands had died or deserted them) and elderly people who could no longer support themselves. It is probable that, during the Famine, many non-settled Irish adult males sought assistance from the poor law and were subsequently removed, but that this was much less common in normal times.

An important additional point to make about Irish removals is that not all of them were by warrant. Some were removed, in common parlance, 'voluntarily'. Indeed, in Liverpool and Glasgow the majority were voluntary. In Liverpool, this applied to around two-thirds of removals in 1847, while in Glasgow it applied to a remarkable 99 per cent. ${ }^{47}$ British poor law officials interviewed by the Select Committee in 1854 defended their record on Irish removals, claiming that they mainly consisted of people who wanted to go back to Ireland. It is certainly true that some removals were of this nature: as we have seen, Irish labourers had for decades come to England and Scotland during the harvest and been returned to Ireland free of charge. Yet there was more to voluntary removals. The Irish nationalist MP, writer and proprietor-editor of the Cork Examiner, John Francis Maguire, a member of the Select Committee, thought 'voluntary' removals were often nothing of the sort, and he repeatedly

\footnotetext{
${ }^{45}$ Unfortunately, the figures do not include ages.

${ }^{46}$ Data from Liverpool between January and April 1847 shows that 53 per cent of 144,112 arrivals from Ireland were adult males. 29 per cent were adult females, and 18 per cent were children: Poor Law Commissioners: Appendices to the Thirteenth Annual Report. Plans, p. 115.

${ }^{47}$ Report from the Select Committee on Poor Removal, 1854, p. 570.
} 
Table 3. Gender of paupers removed from Scotland

\begin{tabular}{ccccccc}
\hline & \multicolumn{3}{c}{ Yr. ending 14 May 1848 } & \multicolumn{3}{c}{ Yr. ending 14 May 1854 } \\
County & Males & Females & $\%$ Male & Males & Females & \% Male \\
\hline Edinburgh & 476 & 407 & 54 & 109 & 216 & 34 \\
Lanarkshire & 4,915 & 4,471 & 52 & 779 & 1,182 & 40 \\
Scotland & 7,098 & 6,571 & 52 & 1,190 & 1,866 & 39 \\
\hline
\end{tabular}

Source: Third Annual Report of the Board of Supervision for the Relief of the Poor in Scotland, BPP, 1849, vol. xxv, Command Paper 1011, p. 125; Ninth Annual Report of the Board of Supervision for the Relief of the Poor in Scotland, BPP, 1854-55, vol. xxiv, Command Paper 1877, p.307.

asked witnesses to explain the nature of this system. ${ }^{48}$ Their answers are revealing, as in the following exchange between Maguire and William Steward Walker, Secretary to the Scottish Board of Supervision:

Maguire: Will you have the kindness to explain distinctly what are voluntary removals; in what manner they are effected?

Walker: The statute provides no particular mode in which they are to be effected. The Board of Supervision requires that there shall be a medical certificate obtained. In some cases, I believe money is paid to the paupers, where they think they can trust them; in other cases the paupers are seen on board a vessel, and the fare paid.

Maguire: In case the pauper does not consent to go of his own accord, he is compelled to go, is he not?

Walker: Then it becomes a matter for the justices.

Maguire: So that voluntary removals do not always represent free will upon the part of the persons removed?

Walker: Not altogether ... there are a large number of parties who know very well that if they do not go willingly they will be made to go. ${ }^{49}$

Under Maguire's questioning, poor law officials from Liverpool and Glasgow made the same admission. ${ }^{50}$ The voluntarily removed were by no means all people who had asked to be returned to Ireland; many had no choice.

\footnotetext{
${ }^{48}$ Maguire served as MP for Dungarvan (1852-65) and Cork (1865-72): S.P. Jones, 'Maguire, John Francis', in J. McGuire and J. Quinn, eds., Dictionary of Irish Biography (Cambridge, 2009), available online at http://dib.cambridge.org/viewReadPage.do?articleId=a5360).

${ }^{49}$ Report from the Select Committee on Poor Removal, 1854, p. 315.

${ }^{50}$ Ibid., pp. 323, 392.
} 
To understand how the Irish might have avoided removal it is necessary to look at the alternatives to the poor law. The range of charitable resources available to the Famine Irish at local levels varied across time and space. Economic circumstances, the size of a locality and the extent of Irish immigration all shaped the range of charitable institutions and the demands placed upon them. As the port closest to Dublin, and as the gateway to the most industrialised region in England, Liverpool bore the brunt of the Famine immigration, and here charitable initiatives were extensive in the late 1840s. The Liverpool District Provident Society (LDPS), supported by voluntary subscriptions, provided relief to 20,489 Irish people in 1847 , up from 6,003 in 1846 (Table 4). ${ }^{51}$ Relief was mainly provided in the form of soup tickets, granting a meal to each applicant. It must be pointed out that not all these Irish were Famine Irish. The augmented number relieved in 1847 also reflected the onset of economic depression in northwest England, as indicated by the increase in the number of non-Irish assisted. Nonetheless, it is very likely that many were recently arrived refugees. Of the 20,489 Irish relieved in 1847 , some 15,024 (73 per cent) were assisted during the months from January to April; this was the period during which Famine Irish immigration was at its most intense. Two other large charitable organisations, the Liverpool Charitable Society (LCS) and the Strangers' Friend Society (SFS), provided relief to thousands of Irish in 1847, although data on both is extremely patchy. We know that in February alone, some 4,716 individuals were relieved by the LCS with soup tickets, and over two-thirds of them were Irish people. ${ }^{52}$ The SFS, which directed its charity specifically at people new to the town, was granting over 80 per cent of its resources to Irish people in the early months of $1847 . .^{53}$

Liverpool also had a Night Asylum, a charitable institution which offered a night or two of free lodging to the homeless; a welcoming sign above the door read 'Knock, and it shall be opened'. ${ }^{54}$ This institution was undoubtedly of great benefit to the Famine Irish. Many new arrivals, particularly those without friends or relatives in Liverpool able to offer temporary accommodation, would have required some time to recover from the voyage and to set themselves up. Some would have needed to recuperate before embarking on a long journey inland to somewhere like Manchester, which was a popular destination for Irish migrants but more than 30 miles from Liverpool. The Night Asylum provided this service. The numbers using the asylum increased very considerably during the first half of 1847 , as

\footnotetext{
${ }^{51}$ Liverpool Mail, 12 Feb. 1848; Liverpool Mercury, 13 Feb. 1849.

${ }^{52}$ Liverpool Mail, 6 Mar. 1847.

${ }^{53}$ Liverpool Mercury, 2 Apr. 1847.

${ }^{54}$ Liverpool Mercury, 25 May 1849.
} 
Table 4. Number relieved by the Liverpool District

Provident Society, 1845-48

\begin{tabular}{ccccc}
\hline Year & $\begin{array}{c}\text { Total number } \\
\text { Relieved }\end{array}$ & $\begin{array}{c}\text { Non-Irish } \\
\text { relieved }\end{array}$ & $\begin{array}{c}\text { Irish } \\
\text { relieved }\end{array}$ & \% Irish \\
\hline 1845 & 6,646 & 3,079 & 3,567 & 55 \\
1846 & 11,845 & 5,842 & 6,003 & 51 \\
1847 & 32,696 & 12,207 & 20,489 & 63 \\
1848 & 18,756 & 9,257 & 9,499 & 51 \\
\hline
\end{tabular}

Sources: Liverpool Mail, 12 Feb. 1848; Liverpool Mercury, 13 Feb. 1849.

migrants poured into the town. In April 1847, over 6,000 people spent at least one night in the asylum, more than double the number of monthly users at the end of 1846. Although we cannot be certain, it is very likely that most of the increase was the result of Famine Irish immigration. Evidence from other places certainly points to this conclusion. Night Asylums and vagrant wards, often run by poor law authorities, were widely used by the Famine Irish. On the well-trodden tramping route between Liverpool and industrial south-east Lancashire, more than 9,000 Irish people spent a night in the vagrant ward at Prescot, and some 12,000 at Warrington. ${ }^{55}$ By all accounts, these numbers were unprecedented. Manchester itself had a Night Asylum much like the one in Liverpool, and in 1847 it accommodated three times as many vagrants as it had in 1846 . More than 31,000 people were sheltered in the institution between January and June 1847, up from 9,700 during the same period the previous year. ${ }^{56}$ Again, many of these were Famine Irish. In June 1847, the Manchester Courier commented that most of the people in the asylum 'appear to be Irish cases', and a month later noted that 'The utility of the institution has been strikingly manifested ... by the large influx of strangers to the town in search of employment, who have been sheltered and relieved' ${ }^{57}$ These 'strangers' would also have been able to get a free meal from the Manchester soup kitchen, opened in January 1847 by the Quaker Society of Friends. Tickets could be obtained from selected subscribers, which provided each recipient with two quarts of soup. The scale of the operation was immense. By the end of January 1847, the soup kitchen was providing 1,500 gallons (12,000 pints) each day. ${ }^{58}$ Bread was also provided. In mid-February 1847, the

\footnotetext{
55 TNA, MH 12/6095, Prescot Union Poor Law Union correspondence, 1 June 1848; Reports and Communications on Vagrancy, BPP, 1847-48, vol. liii, Command Paper 987, pp. 19-20.

${ }^{56}$ Manchester Courier, 12 June 1847.

${ }^{57}$ Manchester Courier, 12 June 1847, 3 July 1847.

${ }^{58}$ Manchester Courier, 27 Jan. 1848.
} 
Manchester Times reported the importance of this charitable endeavour to the Famine Irish in a piece which also hinted at growing concern over the numbers arriving in the town:

\begin{abstract}
During the past week applications at the [soup kitchen] have been very considerably increased ... On Wednesday 1500 gallons of soup and 1500 loaves were distributed ... The streets leading to the soup kitchen have been crowded every day with wretched looking objects, men, women and children, principally Irish, in quest of soup tickets and soup and bread; and from the appearance of the miserable creatures it would appear that the fresh arrivals of Irish poor are added daily to the list of those already in the town. To what extent this migration will be carried, and how long it will continue, are questions of difficult solution. ${ }^{59}$
\end{abstract}

In most large British towns and cities, charitable provision along these lines, if not always on this scale, could be procured by the Famine Irish. This mixed economy of welfare - food, money, short-term accommodation-from various charitable sources undoubtedly provided them with vital assistance. It probably saved many lives. However, to this must be added a crucial caveat: such provision alone did not offer a long-term survival strategy. While the soup kitchens provided crucial nourishment to many Irish refugees, there was no guarantee that tickets would be obtained, and, in any case, most of them had been closed by the end of 1847. With the exception of Liverpool, soup kitchens had been opened mainly for the benefit of the locally unemployed during the depression, and they were closed when it was thought that the economy was picking up. Night asylums and vagrant wards, while again crucial to the coping strategies of many Famine refugees, could only be relied upon in the very short term. In Glasgow, they could not be relied on at all, as demand for space meant that accommodation was restricted to people who had been living in the city for at least one year, explicitly excluding the Famine Irish. ${ }^{60}$ It is also the case that charitable assistance provided by organisations such as the LDPS only granted limited relief in times of great need. The cost to the LDPS of relieving 32,696 families in 1847 was $£ 2,607$, a rate of just $1 s 7 d$ per family. ${ }^{61}$ Vital though these sources of assistance were, they were not enough to live on alone, at least not for very long.

The short-term nature of charitable and poor law provision meant those who wished to remain in Britain had quickly to find alternative forms of support. This was true in normal times as well as during the Famine, but during the late 1840s the process must have been very much more difficult. In Liverpool, weekly poor law expenditure on Irish casual paupers in

\footnotetext{
${ }^{59}$ Manchester Times, 12 Feb. 1847.

${ }^{60}$ Glasgow Herald, 8 Oct. 1847.

${ }^{61}$ Liverpool Mail, 12 Feb. 1848.
} 
1847 fell from $£ 748$ in June to $£ 94$ in October, as some people were removed and others stopped applying for relief for fear of being sent home. ${ }^{62}$ The same pattern is observable elsewhere. Indeed, the evidence indicates that the desire to avoid being shipped back to Ireland meant some non-settled Irish even refused to apply for medical assistance when seriously ill with fever. In these circumstances, getting employment, difficult though it was at a time of economic depression, or receiving help from friends and kin, was essential. Many Famine Irish also turned to begging. At a meeting of the Liverpool Guardians in November 1847 it was stated that the Irish, knowing that 'by applying to the parish, they would be sent back', consequently 'herded in the town and collected alms'. ${ }^{63}$ The scale of the problem rendered the Vagrancy Act inoperable. In Glasgow, the streets were reputedly 'inundated with Irish beggars', and hundreds were imprisoned during the first half of $1847 .{ }^{64}$ Across the urban industrial heartlands of north-west England and central Scotland, the public was urged not to give alms to Irish street beggars, as to do so allowed them to remain in town. The Dublin Evening Packet newspaper summed up poor law policy in Britain at this time as 'carrying the principle of "no Irish need apply" to the workhouse gate' ${ }^{65}$ Certainly, exclusion from parochial relief, and removal for those desperate enough to apply for it, was the experience of many.

The arrival of a large steamer from an English or Scottish port at our quays, is certain to present a scene of much bustle, and no small excitement. Long ere her paddles cease to revolve, loving eyes are strained to catch the first glimpse of some dear object ... But there is one class whom no anxious eyes seek out, to whom no ready hand is extended ... Their eyes are dull and bleared, their steps faltering, their whole appearance indicative of misery and despair ... These are the 'removed poor', who have been got rid of by English, Welsh and Scotch parishes. ${ }^{66}$

This emotive description of the 'removed' Irish disembarking from a steamer in Ireland was written in 1854 by John Francis Maguire, a staunch advocate of abolishing the 'monstrous' laws of settlement and removal in Britain. As a member of the Select Committee on Poor

\footnotetext{
${ }^{62}$ Report from the Select Committee on Poor Removal, 1854, p. 397.

${ }^{63}$ Liverpool Mercury, 12 Nov. 1847.

${ }^{64}$ Devine, 'Great Irish Famine and Scottish History', p. 26.

${ }^{65}$ D.M. MacRaild, “"No Irish Need Apply": The Origins and Persistence of a Prejudice', Labour History Review, lxxviii (2013), pp. 269-99.

${ }^{66}$ John Francis Maguire, Removal of Irish Poor from England and Scotland (London, 1854), pp. 5-6.
} 
Removal in 1854 he had interrogated British poor law officials extensively on their removal practices, as we have seen. ${ }^{67} \mathrm{He}$ was particularly scathing about the removal of persons who had been living in Britain for many years, sometimes decades, without gaining a settlement. Such problems were not new, but the huge numbers removed during the late 1840s brought them into sharp focus and led to renewed demands for reform. ${ }^{68}$ Despite this, the Select Committee in its concluding report actually recommended few changes to the existing system. The weight of opinion among the British poor law officials interviewed, many of whom remembered all too well the difficulties experienced during the Famine, was against substantial reform. They remained resolutely opposed to abolishing the powers of removal. ${ }^{69}$

Maguire's campaign for abolition came at a time when Irish removals had fallen back to pre-Famine levels. During the Famine, the sheer number of removals not only caused untold misery to many thousands of Irish people sent home against their will, but also created major logistical problems at the ports to which they were returned in Ireland. This was because the overwhelming majority of removed Irish paupers were sent to a small number of ports on the east coast. Evidence on this issue is patchy, but data from several sources offer an indicative picture. Table 5 shows the ports to which paupers removed to Ireland from Glasgow (1848-49), Liverpool (1849) and Manchester (1845-47) were sent. It demonstrates that, at the aggregate level, a full 70 per cent of Irish paupers were removed to just two Irish ports: Belfast and Dublin. Within this, however, distinctions are apparent between Glasgow in central Scotland, and Liverpool and Manchester in north-west England.. Glasgow sent almost all its Irish paupers (96 per cent) to either Belfast or Londonderry, which lie respectively on the north-eastern and northern coasts of the province of Ulster. Liverpool and Manchester, on the other hand, mainly sent paupers to the Leinster ports of Dublin and Drogheda, both of which are situated more or less opposite Liverpool on the east coast. This basic geographical dimension to removals reflected, in part, general patterns of Irish migration. Detailed work on Irish migration and settlement in Britain during the nineteenth century shows a clear pattern: the further north the Irish landed in Britain, the further north

\footnotetext{
${ }^{67}$ Ibid., pp. 5-8.

${ }^{68}$ Irish MP William Smith O'Brien, leader of the Young Ireland movement, had complained about the unjust nature of Irish removals in Parliament in 1848: Hansard, Parliamentary Debates, House of Commons, 3rd ser., 29 Feb. 1848, vol. 97, cols. 23-63.

69 The Committee did recommend reducing the period of residency required to become irremovable from five to three years, but this was not introduced until 1861.
} 
Table 5. Geographical distribution of Irish removed from Britain to Ireland

\begin{tabular}{|c|c|c|c|c|c|c|c|c|}
\hline & \multicolumn{2}{|c|}{$\begin{array}{l}\text { Glasgow } \\
1848-49\end{array}$} & \multicolumn{2}{|c|}{$\begin{array}{c}\text { Liverpool } \\
1849 \\
\end{array}$} & \multicolumn{2}{|c|}{$\begin{array}{c}\text { Manchester } \\
1845-47\end{array}$} & \multicolumn{2}{|c|}{ Total } \\
\hline & $\mathbf{N}$ & $\%$ & $\mathbf{N}$ & $\%$ & $\mathbf{N}$ & $\%$ & $\mathbf{N}$ & $\%$ \\
\hline Belfast & 4,443 & 61 & 399 & 4 & 40 & 4 & 4,882 & 27 \\
\hline Drogheda & 0 & 0 & 999 & 11 & 109 & 10 & 1,108 & 6 \\
\hline Dublin & 185 & 3 & 6,749 & 72 & 811 & 75 & 7,745 & 43 \\
\hline Londonderry & 2,583 & 35 & 77 & 1 & 21 & 2 & 2,681 & 15 \\
\hline Other & 80 & 2 & 1,185 & 12 & 103 & 9 & 1,368 & 8 \\
\hline Total N. & 7,291 & 101 & 9,409 & 100 & 1084 & 100 & 17,784 & 99 \\
\hline
\end{tabular}

Sources: Liverpool figures from Report from the Select Committee on Poor Removal, 1854; Manchester figures from TNA, MH 12/6043; Glasgow figures from TNA, HO 45/2847.

Note: 'Other' includes Cork, Dundalk, Newry, Sligo, Portrush, Waterford, Wexford and Youghal. The Glasgow figures include the four parishes of Barony, City, Govan and Gorbals.

they tended to come from in Ireland..$^{70}$ Relatively few Irish arrived in Liverpool from Ulster, and few in Glasgow from Leinster.

The heavy concentration of removals in Belfast and Dublin, and the manner in which paupers were removed, was a cause of serious complaint during the Famine. Local authorities in both cities believed that, in many cases, paupers were sent to their ports simply because they were the most economical (i.e. closest) options available to their British counterparts. In Belfast, Dr William McGee, a member of the poor law Guardians and a vocal critic of British removal practices who gave evidence to the 1854 Select Committee, stated that paupers were often 'abandoned at the seaport nearest to, or most convenient to, Scotland or England, without reference to the place of birth, or the former residence of the parties in Ireland' ${ }^{71} \mathrm{He}$ claimed that some nine-tenths of removals to Belfast were of this type. McGee also complained that paupers were often left at ports located at very considerable distances from their home parishes, and that they were seldom provided with the means of getting themselves there by poor law officials in Britain. McGee was by no means alone in raising this issue, which was also a source of complaint in Dublin. It appears that paupers were usually given, at most, a little food for the voyage over and a shilling or so to support themselves upon arrival in Ireland. The Glasgow authorities were, reputedly, especially parsimonious in their provisions, often giving nothing. Many Irish paupers were effectively

\footnotetext{
${ }^{70}$ M.T. Smith and D.M. MacRaild, 'Nineteenth-Century Population Structure of Ireland and of the Irish in England and Wales: An Analysis by Isonymy', American Journal of Human Biology, xxi (2009), pp. 283-9; eid., 'The Origins of the Irish in Northern England: An Isonymic Analysis of Data from the 1881 Census', Immigrants and Minorities, xxvii (2009), pp. 152-77.

${ }^{71}$ Report from the Select Committee on Poor Removal, 1854, p. 201.
} 
left destitute in Belfast, Dublin or elsewhere, miles from home and with no obvious way of getting there. Maguire recognised this when he referred to paupers being returned to ports 'fifty miles, one hundred miles, or more' from home, asking, 'how are they to reach that distant place, destitute of means, of energy, perhaps of health? ${ }^{72}$

The law was clear enough on the subject of where Irish paupers should be removed to, although it varied slightly between England and Scotland. According to the 1845 Poor Removal Act, English and Welsh poor law authorities were required to remove Irish paupers to one of eight ports-Belfast, Dublin, Cork, Derry, Dundalk, Limerick, Waterford or Wexford-selecting the one nearest to the parish of the pauper's birth or most recent residency. ${ }^{73}$ The only exception to this regulation was in the case of the pauper consenting to being removed elsewhere. It was presumably under this clause that Liverpool and Manchester sent relatively large numbers to the east-coast port of Drogheda, which was not on the schedule. In Scotland, the system was largely the same, but there were no designated ports. Scottish authorities had to send paupers to the port nearest to their home parish unless, again, they consented to going somewhere else. It is likely, as McGee suspected, that English and Scottish authorities often ignored these regulations, particularly during the late 1840s when hundreds of Irish were being sent back from Liverpool and Glasgow each week; Glasgow, for example, sent very few paupers as far as Sligo, despite many Irish migrants having arrived from the north Connacht region during the Famine.

A further source of complaint in Belfast and Dublin during the Famine, and indeed thereafter, was that many removals were illegal. When inquiries into allegations of illegal removal took place, however, the offence was rarely proven. The testimony of paupers was always heard with some degree of suspicion, and opinion usually went in favour of the British authorities who removed them. Even when cases were found to have been illegal, there was little retribution. The example of Elizabeth Moore and Elizabeth Holt, two of thirty-seven Irish paupers removed on a single day in July 1847 from the Bolton poor law union in north-west England, is illustrative. Moore had been living in the township of Great Bolton for thirty years, Holt for eleven. Both were legally settled there. Moore, who had never lived in Ireland, was removed without a warrant, while the fact that Holt was married (the ground upon which she had established settlement in Bolton) was omitted from evidence presented to the magistrate who signed the removal warrant. Both of these women were sent

\footnotetext{
${ }^{72}$ Maguire, Removal of Irish Poor, p. 5.

${ }^{73}$ Maguire provides a detailed overview of these regulations: ibid., pp. 9-14.
} 
to Dublin. Moore, having never lived in Ireland, had nowhere to go, while Holt's home parish of Belturbet, where she had not lived for more than a decade, was some 80 miles away. Neither of these women had been given any food or money for the voyage over. While the inquiry concluded that the removals were a result of 'great negligence' on the part of the Great Bolton officials, it stopped short of advocating the dismissal of the officer who conducted the removal, due to the 'difficulties with which he had to contend, arising from the sudden influx of so large a body of Irish paupers'. ${ }^{74}$ Moreover, the Bolton Guardians refused to reimburse North Dublin, the union which brought the charges. ${ }^{75}$ The result was a victory for North Dublin union, but an empty one with few practical consequences. Outcomes such as this, as evidence from the 1854 Select Committee indicates, meant that Irish authorities generally only pursued the most egregious cases of illegal removal.

It is apparent that upon arriving in Ireland paupers had only a very limited number of choices, and the expectation of the authorities there was that they would return immediately to their parish of birth or most recent Irish residence. It is certainly the case that little was offered to them by way of welfare. During the late 1840s the authorities in Belfast and Dublin, like their counterparts across the sea in Liverpool and Glasgow, were applying measures designed to combat the twin problems of overcrowding and disease associated with mass inflows of people. They had to contend not only with thousands removed from Britain, but also with huge numbers of people coming from other parts of Ireland affected by famine. Outdoor relief was, for all intents and purposes, unavailable to those arriving in Belfast and Dublin at this time, whether from elsewhere in Ireland or from Britain. If a removed Irish pauper went to the poor law authorities for assistance, they were sent to the workhouse as a matter of course. The policy was intended to discourage applications. As one poor law Guardian in Belfast stated in 1849, had the Board not 'resolutely refused to recognise the principle of outdoor relief', the rates would have increased considerably as a result of relieving paupers sent from Britain. ${ }^{76}$ The Vagrant Act, which prohibited public begging, was also strictly applied in Belfast and Dublin during the Famine in order to discourage in-

\footnotetext{
${ }^{74}$ Freemans Journal, 30 Dec. 1847.

75 North Dublin Union [hereafter NDU], Guardians' minutes, 10 May 1848 (available via Findmypast [D.C. Thomson, 2006-], at http://www.findmypast.co.uk). Dublin had two poor law unions: North Dublin and South Dublin. The burden of removed paupers fell upon North Dublin, as it was here that the paupers were landed.

${ }^{76}$ Northern Whig, 3 Mar. 1849. In Dublin, in December 1847, it was stated that all paupers unable to make their way to their home parish 'had to be put in the workhouse': Freeman's Journal, 30 Dec. 1849.
} 
migration from the country and to encourage destitute non-residents to leave. ${ }^{77}$ As in Liverpool and Glasgow, many beggars and vagrants were imprisoned. ${ }^{78}$

Facing these punitive measures, paupers removed to Belfast and Dublin had little choice but to find some way of getting home. This presented an immediate problem for the authorities, as in many cases their home parishes were not within walking distance. While the Laws of Settlement and Removal in Britain allowed poor law authorities to expend funds to transport paupers to their parishes of settlement within England, Scotland and Wales, in Ireland the absence of a parish-based settlement system meant this was not possible. A solution was found in private charity. In Belfast and Dublin, and, it seems, to a limited extent in other Irish port towns, charitable funds were directed towards returning people home. ${ }^{79}$ In Dublin, a fund was organised for this purpose in 1847 by the Lord Mayor, Michael Staunton, a member of the Repeal Association and chair of the North Dublin Board of Guardians, who was deeply critical of British removal policy at this time. The exact nature of the initiative and how it was funded is not entirely clear, but by early 1848 some 5,000 people had been assisted home 'after their transmission from England' ${ }^{80}$ The benefit of this scheme was noted by one North Dublin Guardian, who stated that without such provision they would have had to support removed Irish paupers out of the poor rates, 'for in all instances where poor people were not able to travel to their places of destination they had to be put into the workhouse'. ${ }^{81}$ Staunton stated at a meeting of the Guardians in December 1847 that the funds were running dry, and it is not clear if more were procured. The scheme was still active in February 1848, but we hear nothing of it thereafter. If it ended, the experiences of many people removed to Dublin must have been very much more difficult.

In Belfast, charitable provision of this nature was more impressive still. Complaints against the iniquities of removals from Britain were heard louder and endured longer in Belfast than in Dublin, mainly because two individuals in the town, John Holden Esq. and the aforementioned Dr William McGee, made the issue a cause célèbre. Both were members of the Belfast Board of Guardians and the town council, and the highly respected McGee served as Mayor of Belfast in 1853. They were also involved with a number of charitable organisations in the town, including the Belfast Charitable Society, whose role included not just assisting the poor but tackling a range of social problems; a major focus for the

\footnotetext{
${ }^{77}$ C. Ó Murchada, The Great Famine: Ireland's Agony, 1845-1852 (New York, 2011), p. 100.

78 Ó Gráda, Black' 47 and Beyond, pp. 94, 187.

${ }^{79}$ Report from the Select Committee on Poor Removal, 1854, pp.141-4.

${ }^{80}$ The Pilot, 25 Feb. 1848.

${ }^{81}$ Freeman's Journal, 30 Dec. 1847.
} 
organisation in 1847 was the suppression of street begging. ${ }^{82}$ Holden and McGee regularly raised the issues of paupers being illegally removed, sent over without food or money, left at Belfast despite their home parishes being far closer to other ports and of being sent in a state of ill health. ${ }^{83}$ It was Holden who took charge of administering resources to assist paupers to return to their home parishes. Funds were appropriated for this purpose from around July 1847 out of resources belonging to the Belfast General Relief Fund (BGRF), a charity formed in January 1847 for the relief of destitute persons across the country. By December 1848, some 11,224 people removed from Britain had been sent 'to their alleged place of birth' by the charity. ${ }^{84}$ This provision, which continued to assist removed Irish paupers into the $1850 \mathrm{~s}$, granted them 'food ... and money where necessary and paid their railway fare or sent them by cart towards their home'. ${ }^{85}$ The importance of the organisation is apparent in the fact that it assisted 93 per cent of an estimated 12,100 paupers who arrived in Belfast from Britain between July 1847 and January $1849 .{ }^{86}$ As quickly as paupers were coming in, this initiative was ensuring they were moved out.

\section{III}

There was another important aspect to this provision: in some cases, paupers were helped to return to Britain. Paupers removed from England, Scotland or Wales were occasionally anxious to go back as soon as possible, particularly when they had lived abroad for some years and had established work and kinship ties there. While the proportion who did return probably constituted only a small minority of the total, it was certainly not uncommon for British officials to find people back in town shortly after being removed, and they were occasionally imprisoned for it. The use of charitable provision for this purpose is of particular interest in Belfast. Very few paupers, it appears, were helped back across the Irish Sea from Dublin. According to officials, such cases numbered just forty, less than 1 per cent of the total assisted by Staunton's charitable fund.$^{87}$ In Belfast, however, the figure was much

\footnotetext{
${ }^{82}$ Northern Whig, 23 Feb. 1847.

${ }^{83}$ Public Record Office of Northern Ireland [hereafter PRONI], records of the Board of Guardians, BG/7/A/6, 15 June 1847, 12 Jan. 1848 and 26 Jan. 1848; BG/7/A/7, 15 Mar. 1848; BG/7/A/8, 3 Feb. 1849, 20 Feb. 1849 and 27 Feb. 1849; Northern Whig, 3 Mar. 1849; Belfast Protestant Journal, 3 Feb. 1849; Belfast News Letter, 3 Apr. 1849; Northern Whig, 3 Apr. 1849.

${ }^{84}$ PRONI, BG/7/A/8, 9 Dec. 1848.

${ }^{85}$ PRONI, BG/7/A/6, 12 Jan. 1848.

${ }^{86}$ Northern Whig, 3 Apr. 1849.

${ }^{87}$ Freeman's Journal, 30 Feb. 1847.
} 
higher, reportedly numbering 295 individuals. ${ }^{88}$ While these, too, represented only a small proportion of the total assisted by the BGRF, the practice brought the Belfast authorities into a protracted dispute with their counterparts in Glasgow, where the majority of the Irish returned from Belfast to Britain were landed.

Conflict between British and Irish authorities over removed Irish paupers returning to England and Scotland emerged as part of wider controversies surrounding Irish immigration and removal during the Famine. Both sides felt aggrieved about the influx of destitute Irish landing at their ports. ${ }^{89}$ The issue came to a head in February 1849, following the removal from Glasgow to Belfast of one Jean Cairns and her newborn child..$^{90}$ Cairns, a 20-year-old domestic servant who came to Glasgow in 1845, gave birth to an illegitimate child in December 1848. She was supported by the Glasgow poor law authorities for ten weeks following the child's birth, before they removed her under warrant to Belfast. She left Glasgow on 6 February and arrived in Belfast the following day. Yet her home parish of Boyle, County Roscommon, was 120 miles away. With nowhere to go, Cairns made her way to the BGRF offices, and after explaining her case to Holden she was swiftly sent back to Scotland. On 8 February, just two days after being removed from Glasgow, she was back in the city. On arrival, Cairns entered the Glasgow city poorhouse, her return prompting an immediate response from the Glasgow authorities. She was brought before two magistrates who took her sworn testimony, and the Glasgow poor law Guardians decided to send her statement to the Board of Supervision and the Privy Council. On 22 February, Cairns was removed by warrant from Glasgow for the second time in less than three weeks. Landing in Belfast on 24 February, she once again made her way to the BGRF offices and was soon back on a ship headed for Glasgow, where she arrived on 28 February.

Beyond its anecdotal value, the case has much to say about the responses of the authorities to Irish pauperism; about the conditions and circumstances which shaped their decisions; and about the experiences of those caught in the removal process. The decision of the Glasgow authorities to forward evidence of the Cairns case to the government must be understood in terms of broader efforts to curb Irish immigration. In a report accompanying

\footnotetext{
${ }^{88}$ Report from the Select Committee on Poor Removal, 1854, pp. 355-6.

${ }^{89}$ Another case, outside our geographical compass, saw a strained series of exchanges between Guardians in Newcastle, Armagh, Dublin and London, over the removal of a man who had been living in Britain for forty-six years: Correspondence between Poor Law Commissioners in Ireland and England relative to removal of John McCoy from Newcastle upon Tyne to Armagh, BPP, House of Commons Papers, 1849, vol. xlvii, no. 159. See also Kinealy, This Great Calamity, p. 340.

${ }^{90}$ The following evidence is taken from PRONI, BG/7/A/8; TNA, HO 45/2847, letters from Glasgow relating to the removal of Irish paupers; Northern Whig, 3 Mar. 1849; Glasgow Herald, 3 Feb. 1849, 5 Mar. 1849, and 19 Mar. 1849.
} 
Cairns's testimony, the Glasgow Guardians reminded the government that they were still being 'inundated with paupers from Ireland', and demanded tighter regulations on steamships bringing them over. ${ }^{91}$ On top of this was a sense of injustice fuelled by the actions of the Belfast authorities. Since the Irish influx began in late 1846 there had been an underlying assumption in Glasgow, so too in Liverpool, that many Irish migrants had been assisted in coming to Britain by landowners and other wealthy figures. Indeed, the Guardians' report on Cairns mentioned their enduring conviction that 'too many of these unhappy and wretched creatures are shipped from Ireland to Scotland at the instance of Irish proprietors for the premeditated purpose of relieving themselves of the duty of supporting them' ${ }^{92}$ The discovery that some paupers legally removed from Glasgow were back in the city shortly afterwards, and that their return had been facilitated by prominent officials in Belfast, seemed to confirm these fears and constituted a serious affront.

Cairns's case was quickly picked up by the press. It was reported in newspapers across Scotland in February and March 1849, and even made the London papers. ${ }^{93}$ It received extensive coverage in Glasgow. The case prompted the Glasgow Herald to run a series of provocative articles titled 'Irish treatment of Irish paupers', which attacked the 'inhuman and unjust' actions of the Belfast authorities in their treatment of Cairns and others like her. ${ }^{94}$ 'Irish paupers', claimed the paper, 'are sent to Ireland at the expense of the parishes of Glasgow; and there they are apprehended, and as speedily as possible sent back'. ${ }^{95}$ Over in Belfast, Holden vehemently refuted these claims. In a lengthy discussion among the Belfast Guardians, it was agreed that a statement detailing the Cairns case, and exposing the fallacies inherent in the Herald reports, should be placed in the Northern Whig, a Belfast newspaper. ${ }^{96}$ A letter by Holden was also published in the London newspaper The Times. ${ }^{97}$ He stated that Cairns was not apprehended, but asked to be returned to Glasgow, where the father of her child was still living. Moreover, in defending Belfast, Holden turned his attention to the actions of the Glasgow authorities, who, he pointed out, had effectively abandoned a young mother and her child 120 miles from home. He stated that, in compliance with the law, Cairns should have been removed to the west-coast port of Sligo, 25 miles from her parish. The

\footnotetext{
${ }^{91}$ TNA, HO 45/2847, letters from Glasgow relating to the removal of Irish paupers.

92 Ibid.

${ }^{93}$ See, for example, Perthshire Advertiser, 15 Feb. 1849; Dundee, Perth and Cupar Advertiser, 13 Mar. 1849; Greenock Advertiser, 13 Mar. 1849; London Daily News, 26 Mar. 1849.

${ }^{94}$ See Glasgow Herald, 12 Feb. 1849, 5 Mar. 1849, 19 Mar. 1849, and 9 Apr. 1849.

${ }^{95}$ Glasgow Herald, 12 Feb. 1849.

96 PRONI, BG/7/A/8, 20 Feb. 1849.

${ }^{97}$ The Times, 20 Feb. 1849.
} 
complaints were echoed by McGee at a council meeting, where he used the opportunity to complain of the 'grievous burden' imposed upon Belfast by the removal of paupers from Glasgow, and the 'hardship to which these people were subjected' ${ }^{98}$ To McGee and Holden, Cairns and many other paupers were being unjustly removed from Glasgow under a policy of indiscriminate removal, and, far from being 'inhumane', assisting them to return was the fairest way to ameliorate their situation.

In the middle of all this was Jean Cairns herself. It is difficult to judge exactly what her circumstances were, as the information she gave officials at Belfast and Glasgow was inconsistent. On first being removed to Belfast, Cairns told Holden that she was a married woman whose Scottish husband, the father of her newborn child, was still in Glasgow. ${ }^{99}$ Based on this evidence, the removal was illegal, as Cairns had earned settlement through marriage. Holden consequently agreed to send her back. She had, however, lied; she was unmarried. Upon returning to Glasgow, where her true circumstances were known, she presented a different story. Brought before the magistrates, she claimed to have been mistreated in Belfast. She was, she told them, locked in a small room, which was 'dirty, several windows broken', for twelve hours with her baby and several other people. They had 'some water, but received no food' ${ }^{100}$ By the time Cairns had been removed to Belfast for the second time, her testimony in Glasgow had received attention on both sides of the Irish Sea. She defended her statements to Holden, who once again interviewed her, and claimed that 'the words were put into [my] mouth'. ${ }^{101}$ She also admitted to being unmarried, and said she had lied as she was 'ashamed to tell of my own disgrace'. Cairns did, however, maintain that the putative father was still in Glasgow, that he was in employment, and that she was desirous to return to get the child affiliated. It was on these grounds that Holden had agreed to return her to Glasgow for a second time.

We do not know what happened to Cairns after her second return to Glasgow. We can, however, consider some of her motivations. It is clear that she was determined to live in the city, and this is hardly surprising. Cairns was a young woman who had resided in Glasgow for most of her adult life. Having spent five years there, she would have developed kinship ties and friendship networks in the area. The father of her child was in the city. Moreover, there would have been little waiting for her in Boyle, a small parish in a region still suffering

\footnotetext{
${ }^{98}$ Northern Whig, 3 Mar. 1849.

${ }^{99}$ See Glasgow Herald, 13 Mar. 1849.

${ }^{100}$ Glasgow Herald, 12 Feb. 1849.

${ }^{101}$ Northern Whig, 12 Mar. 1849; Glasgow Herald, 13 Mar. 1849.
} 
from the effects of Famine. The stigma of unmarried motherhood would also have been greater there. Her desire to reside in Glasgow influenced the statements she gave to both sides. By claiming in Belfast that her husband was still in Glasgow, Cairns was playing her strongest card. She must have known that Holden would return her under this circumstance. The same is true of her later claim that she knew who the putative father was in Glasgow, and that he was able to support them. Her claims of mistreatment by Belfast officials are rather more difficult to unpick. Perhaps she was pressured by the Glasgow authorities to make those statements. It might also be the case that Cairns wanted to evoke sympathy by telling them that she, and her baby, would be treated cruelly if sent back. In any case, she told the Belfast and Glasgow authorities what she thought they wanted to hear, and what she understood as offering the best chance of a favourable outcome. The Cairns case is untypical in the sense that it was at the centre of a major dispute receiving considerable press attention. Yet the experiences of the thousands of people caught in the removal net during the Famineuncertainty, dislocation, hardship — would have been much the same.

The legacy of the Famine meant that cases of unjust, if not illegal, removals such as Cairns's continued throughout the 1850s. People were removed after living in Britain for many years, sometimes decades. Those who gained 'irremovable' status after residing in a parish for five consecutive years lost that status if they moved to another parish, and so could then be removed. Many such cases occurred. Yet, although the Famine revealed all too clearly that the Irish were at the sharp end of Britain's removal laws, and despite persistent complaints from Irish poor law authorities and MPs such as Maguire about British removal practices, there remained strong opposition to significantly reforming or abolishing the laws governing settlement and removal. Fears that the crisis of the late 1840s would be repeated, and that once again British ports would be swamped by destitute Irish, stifled attempts to initiate meaningful change despite the inherent and widely recognised cruelty of the existing system. 'Liverpool appears to be in a perfect flutter of apprehension', wrote Maguire in 1854, 'at the bare idea of touching the power of removal'. ${ }^{102}$ In 1857, the Earl of Donoughmore, suggesting in the House of Lords that the Government might consider amending some of the harsher aspects of the removal laws, anticipated the grounds on which this might be opposed: 'Owing to the great number of Irish paupers who had, during the famine of 1847, come over to the western coast of England, the poor-law authorities ... might object to any proposal by

102 Maguire, Removal of Irish Poor, p.89. 
which they would be saddled with a population of that description'. ${ }^{103}$ A full decade after the worst year of the Famine, its foreboding shadow continued to linger.

\section{IV}

What we can observe of Irish removals during the Great Famine was, in one sense, nothing new or unusual. By 1847, large-scale Irish immigration to parts of England, Scotland and Wales was already a long-established fact of urban life, and for decades before the Famine thousands of Irish men, women and children had been returned back home by British poor law authorities each year. Negative perceptions of Irish migrants as disease-carrying mendicants, particularly in urban centres, pre-dated the Famine, and the Irish were always much more likely to face removal proceedings than their British counterparts. At home in Ireland, complaints about illegal or unjust British removal practices also pre-dated the mass deportations of the late 1840s, and endured thereafter. What the Famine removals did produce, however, was a new pitch of intensity. The sheer number of destitute Irish moving in both directions across the Irish Sea, particularly in the years 1847-48, was unprecedented, and created additional problems in Britain and Ireland with significant short- and long-term implications for those at the centre of the maelstrom: the Irish poor themselves. It is crucial to emphasise that the mass movement of Irish during the Famine was by no means a one-way process. Too often, we read of the Famine exodus without any recognition that a significant minority of the refugees were returned to Ireland against their will, and often left destitute at ports situated many tens of miles from their 'homes'.

This article has attempted to extend the scope of our understanding of removals and of the assumptions underpinning them. We have shown that the same problems facing the authorities in Liverpool, Glasgow and other British towns and cities heavily affected by the Irish influx were also experienced in Belfast and Dublin, as thousands of impoverished Irish arrived from Britain each week alongside many more from famine-ravaged parts of the country. Responses to the arrival of these destitute masses on both sides of the Irish Sea were remarkably similar and undoubtedly punitive, although these reactions have to be seen in the context of heavy burdens on local tax-payers and the undoubted public health hazards associated with disease-carrying Irish paupers. The authorities implemented measures with the primary intentions of protecting the poor rates and halting the spread of infectious diseases by encouraging or forcing the non-settled Irish to leave. Restrictions were placed on

${ }^{103}$ Hansard, Parliamentary Debates, House of Lords, 3rd ser., vol. 146, 30 Jun. 1857, cols. 616-19. 
outdoor relief, and mendicancy was targeted. Charitable provision, though extensive, only provided very short-term assistance. Many non-settled Irish, turning to the poor law as a last resort, quickly found themselves in a system intent on shovelling them out as quickly as possible. It is difficult to see, however, how the authorities could have acted differently, especially at Liverpool and Glasgow, where the number of refugees arriving each week was overwhelming. Devoid of assistance from national government despite repeated appeals, removal was the only way they could protect themselves.

The events of the late 1840s had far-reaching implications for the Irish in Britain. In 1849, the nationwide social surveys of the Morning Chronicle revealed Irish communities in all the industrial cities living in poverty and hardship. In often lurid language, the Irish were stigmatised as a type of underclass. They were described as dwelling in 'haunts' and cellars; living alongside pigs and calves; occupied in labouring and street trading; and often prone to drinking and violence. ${ }^{104}$ In the 1850 s, even after the Famine had subsided, the Irish were noticeable in social statistics. They were over-represented among those receiving poor relief, just as they were in the magistrates' proceedings that dealt with drunken violence, or among the inmates of British prisons. ${ }^{105}$ This remained the case in the mid-Victorian years. The Irish in Britain constituted a marginal group at the outer edge of the working class. Poverty, a desperate need for alms, religious difference and national prejudice: each contributed to the perpetuation of their marginal status. Throughout the 1850s, fears that the Irish would overwhelm poor law authorities should the power of removal be revoked-a legacy of the Famine-were at the centre of opposition to significantly amending the Laws of Settlement and Removal.

Much more remains to be discovered about the Famine Irish in Britain, and indeed in Ireland. In the context of the present discussion, one issue cries out for further investigation. What, ultimately, happened to those despatched to their parishes from Belfast and Dublin, at a time when famine still stalked the land? We can follow the painful journeys of those who were sent back and forth as freight in the disputes between poor law authorities on either side of the Irish Sea. Some of those who were returned and dumped, we assume, must have perished. Most no doubt survived, but in what manner, in which localities and drawing on

\footnotetext{
104 Outside London (which Henry Mayhew explored), the results of the surveys are reprinted, with a long introduction, in Labour and the Poor in England and Wales, 1849-1851: The Letters to the Morning Chronicle from the Correspondents in the Manufacturing and Mining Districts, the Towns of Liverpool and Birmingham, and the Rural Districts, ed. J. Ginswick (8 vols, London, 1983).

${ }^{105}$ MacRaild, Irish Diaspora, pp. 167-70; D. Fitzpatrick, 'A Curious Middle Place: The Irish in Britain, 18711921', in Swift and Gilley, eds., Irish in Great Britain, pp. 10-59, esp. tables 1.5 and 1.6 at pp. $26-8$.
} 
what resources? These people numbered many thousands, and their stories are an important part of the history of the Great Famine. Whether they can be retrieved from the dark abyss of those terrible times must for the moment remain an open question.

University of Roehampton

London Metropolitan University

University of Roehampton

Queens University Belfast

\section{LEWIS DARWEN}

DONALD MACRAILD

BRIAN GURRIN

LIAM KENNEDY 